\title{
An Approach to What Could Be Covered in an IS MBA Course, and How It Could Be Delivered
}

\author{
K. A. Johnston \\ University of Cape Town, Cape Town, South Africa
}

Kevin.johnston@uct.ac.za

\begin{abstract}
When asked to deliver an IS MBA course, two questions arise; what material could and should be covered, and how could the course be delivered? The IS module of an MBA is usually a compulsory module at an advanced level. Rather than finding, adopting and following a text book, the issue of CIO concerns was investigated, and a syllabus built around these issues using case studies. Students then had to research, present and question the case studies. The result was that students engaged with, and integrated IS with other MBA modules.
\end{abstract}

Keywords: Course Content, Course delivery, IS MBA.

\section{Introduction}

When asked to deliver an Information Systems (IS) MBA course, two questions arise; what material could and should be covered, and how could the course be delivered? One approach is to search for, and find a suitable text book on which to base the course. A wide range of excellent text books have been created for IS MBA courses, including the widely used books by the following authors (Laudon \& Laudon, 2012; Pearlson \& Saunders, 2010). These text books come with useful and helpful supporting material for lecturers as well as students. Materials include lecture resources (PowerPoint slides and lecture notes), companion websites, text banks, and case studies.

Academics should however continually challenge and question all systems, including the curricula, societal and market demands, and teaching methods (Johnston, 2010). So instead of finding, adopting and following a textbook such as Laudon and Laudon (2012), a questioning approach was followed. Questions such as what are the key Information Systems issues concerning management at present, how do management decide where they should allocate time and resources, how do management prioritize were asked.

A literature search was conducted using Google Scholar and a University Library to find relevant academic journal and conference articles on key issues for IS management. The search was then

Material published as part of this publication, either on-line or in print, is copyrighted by the Informing Science Institute. Permission to make digital or paper copy of part or all of these works for personal or classroom use is granted without fee provided that the copies are not made or distributed for profit or commercial advantage AND that copies 1) bear this notice in full and 2) give the full citation on the first page. It is permissible to abstract these works so long as credit is given. To copy in all other cases or to republish or to post on a server or to redistribute to lists requires specific permission and payment of a fee. Contact Publisher@InformingScience.org to request redistribution permission. broadened to find non-academic and business articles related to the topic.

The next section details the results of the literature search; this is followed by the development of the framework for an MBA IS module presented at a university in Germany in 2011. The paper then details how the module was taught and presented, followed by the conclusion which looks at the results. 


\section{What are the Key Information Systems Issues Concerning Management?}

"Since 1980, the Society for Information Management (SIM), in a joint effort with different academic leaders, has conducted an annual survey of the key issues facing IT executives in the United States" (Luftman \& Ben-Zvi, 2010, p. 49). These annual surveys have been repeated in many countries, and the latest surveys include European, South East Asian, and Latin American countries (Luftman \& Zadeh, 2011).

The recent SIM surveys provide two major lists; the most influential technologies, and the top IS management concerns. The technologies and issues have changed over time as expected, but for the purposes of this paper only the most recent survey results were examined.

The top application and technology developments as ranked by 472 respondents in the most recent SIM survey (Luftman \& Zadeh, 2011) are as detailed in Table 1. Several of these such as cloud computing, SaaS, and virtualization are hardly if at all covered in any detail in most textbooks.

\begin{tabular}{|l|l|l|l|l|l|}
\hline \multicolumn{7}{|c|}{ Table 1: Top Application and Technology Developments (Luftman \& Zadeh, 2011) } \\
\hline & Global & US & Europe & $\begin{array}{l}\text { SE Asia (inc } \\
\text { Australia) }\end{array}$ & $\begin{array}{l}\text { Latin } \\
\text { America }\end{array}$ \\
\hline Business intelligence & 1 & 1 & 3 & 2 & 2 \\
\hline Cloud computing & 2 & 5 & 1 & 3 & 3 \\
\hline $\begin{array}{l}\text { Enterprise resource planning (ERP) } \\
\text { systems }\end{array}$ & 3 & 3 & & 1 & 4 \\
\hline Software as a Service (SaaS, PaaS) & 4 & & 2 & & 5 \\
\hline Collaborative and workflow tools & 5 & & & & 1 \\
\hline Business process management systems & 6 & & 4 & 5 & \\
\hline Virtualization & 7 & 2 & & & \\
\hline Continuity planning/disaster recovery & 8 & 4 & & & \\
\hline Microsoft upgrade & 9 & & & 4 & \\
\hline Security & 10 & & 5 & & \\
\hline
\end{tabular}

The top management concerns of the respondents across a wide range of industries are as detailed in Table 2 (Luftman \& Zadeh, 2011). The number one concern, business productivity and cost reduction could perhaps be there as a result of the global economic downturn which commenced in $2007 / 8$, as can be seen in Table 3 .

\begin{tabular}{|l|l|l|l|l|l|}
\hline \multicolumn{7}{|l|}{ Table 2: The top IT management concerns (Luftman \& Zadeh, 2011) } \\
\hline & Global & US & Europe & $\begin{array}{l}\text { SE Asia (inc } \\
\text { Australia) }\end{array}$ & $\begin{array}{l}\text { Latin } \\
\text { America }\end{array}$ \\
\hline Business productivity and cost reduction & 1 & 1 & 1 & 1 & 1 \\
\hline IT and business alignment & 2 & 3 & 3 & 2 & 3 \\
\hline Business agility and speed to market & 3 & 2 & 4 & 6 & 2 \\
\hline $\begin{array}{l}\text { Business process management \& re- } \\
\text { engineering }\end{array}$ & 4 & 5 & 2 & 3 & 4 \\
\hline IT reliability and efficiency & 5 & 4 & 6 & 4 & 8 \\
\hline Revenue-generating IT innovations & 6 & 7 & 7 & 6 & 7 \\
\hline IT strategic planning & 7 & 6 & 7 & 9 & 5 \\
\hline IT cost reduction & 8 & 8 & 5 & 14 & 11 \\
\hline Project management & 9 & 16 & 18 & 6 & 6 \\
\hline
\end{tabular}




\begin{tabular}{|l|l|l|l|l|l|}
\hline Globalization & 10 & 10 & 15 & 10 & 13 \\
\hline Security and privacy & 11 & 9 & 20 & 11 & 9 \\
\hline Enterprise architecture & 12 & 13 & 11 & 12 & 14 \\
\hline Considerations of IT human resources & 13 & 14 & 16 & 5 & 16 \\
\hline Change management & 14 & 11 & 11 & 16 & 15 \\
\hline Knowledge management & 15 & 15 & 17 & 12 & 10 \\
\hline Supplier management/Outsourcing & 16 & 12 & 7 & 18 & 19 \\
\hline Leadership role of CIO & 17 & 20 & 11 & 19 & 12 \\
\hline Sourcing decisions & 18 & 17 & 7 & 20 & 20 \\
\hline Social implications of IT & 19 & 19 & 19 & 17 & 17 \\
\hline Design in the IT area & 20 & 21 & 21 & 14 & 18 \\
\hline
\end{tabular}

Table 3 shows a history of IT management concerns from 2003 to 2010, which shows how some concerns have remained in the top 10 (such as IT and Business Alignment, and IT strategic planning), many other have surfaced recently (IT reliability and efficiency, Revenue-generating IT innovations, and Globalization), while others have disappeared (Attracting, developing and retaining IT staff was number 2 in 2004 and 2005) (Luftman \& Ben-Zvi, 2010).

\begin{tabular}{|l|l|l|l|l|l|l|l|l|l|}
\hline \multicolumn{7}{|l|}{ Table 3: A history of IT Management concerns (Luftman \& Ben-Zvi, 2010) } \\
\hline IT Management concerns & $\mathbf{2 0 1 0}$ & $\mathbf{2 0 0 9}$ & $\mathbf{2 0 0 8}$ & $\mathbf{2 0 0 7}$ & $\mathbf{2 0 0 6}$ & $\mathbf{2 0 0 5}$ & $\mathbf{2 0 0 4}$ & $\mathbf{2 0 0 3}$ \\
\hline $\begin{array}{l}\text { Business productivity and cost } \\
\text { reduction }\end{array}$ & 1 & 1 & 7 & 4 & & & & \\
\hline $\begin{array}{l}\text { Business agility and speed to mar- } \\
\text { ket }\end{array}$ & 2 & 3 & 13 & 17 & 7 & & 5 & 7 \\
\hline IT and business alignment & 3 & 2 & 1 & 2 & 1 & 1 & 1 & 1 \\
\hline IT reliability and efficiency & 4 & 6 & & & & & & \\
\hline Business process re-engineering & 5 & 4 & 18 & 15 & 11 & 5 & 10 & 10 \\
\hline IT strategic planning & 6 & 7 & 3 & 8 & 4 & 4 & 4 & 2 \\
\hline Revenue-generating IT innovations & 7 & 8 & & & & & & \\
\hline IT cost reduction & 8 & 5 & 7 & 4 & & & & \\
\hline Security and privacy & 9 & 9 & 8 & 6 & 3 & 2 & 3 & 3 \\
\hline Globalization & 10 & 15 & & & & & & \\
\hline
\end{tabular}

The idea then arose that a set of seminars could be developed from these results. The first set of 10 seminars could be based on the technological issues from Table 1, while the 20 management issues in Table 2 could provide a focus for managerial IS issues.

The next step was to examine what non-academic researchers and business articles said about the topic. Here two main sources were used, Gartner and IBM. Gartner (McDonald \& Aron, 2011; Raskino, 2011) asked CIOs to provide, in a free-form manner, their top 3 business strategies, CIO strategies and technologies. McDonald and Aron (2011) then categorized the CIO responses into groups and then used these groups to rank CIO priorities in the top 10 lists. Interestingly, the Gartner surveys are also broken down into technological and management issues, as shown in Tables 4 and 5. 


\begin{tabular}{|l|l|l|l|l|}
\hline \multicolumn{5}{|c|}{ Table 4: CIO Technology priorities (McDonald \& Aron, 2011) } \\
\hline CIO Technologies & $\begin{array}{l}\text { Ranking of technologies CIOs selected as one of } \\
\text { their top 3 priorities in 2011 }\end{array}$ \\
\hline Ranking & $\mathbf{2 0 1 1}$ & $\mathbf{2 0 1 0}$ & $\mathbf{2 0 0 9}$ & $\mathbf{2 0 0 8}$ \\
\hline Cloud Computing & 1 & 2 & 16 & \\
\hline Virtualization & 2 & 1 & 3 & 3 \\
\hline Mobile Technologies & 3 & 6 & 12 & 12 \\
\hline IT Management & 4 & 10 & & \\
\hline Business intelligence (BI) & 5 & 5 & 1 & 1 \\
\hline Networking, voice and data communications & 6 & 4 & 6 & 7 \\
\hline Enterprise applications & 7 & 11 & 2 & 2 \\
\hline Collaboration technologies & 8 & 10 & 5 & 8 \\
\hline Infrastructure & 9 & 14 & 7 & 6 \\
\hline Web 2.0 & 10 & 3 & 15 & 15 \\
\hline
\end{tabular}

If one compares the technology tables (Tables 1 and 4), it is apparent that there are many similarities and overlaps between the SIM and Gartner surveys.

\begin{tabular}{|l|l|l|l|l|l|}
\hline \multicolumn{7}{|c|}{ Table 5: Global business strategies (McDonald \& Aron, 2011) } \\
\hline Business strategies & \multicolumn{5}{l|}{$\begin{array}{l}\text { Ranking of business strategies CIOs selected as one of } \\
\text { their top 3 }\end{array}$} \\
\hline Ranking & $\mathbf{2 0 1 1}$ & $\mathbf{2 0 1 0}$ & $\mathbf{2 0 0 9}$ & $\mathbf{2 0 0 9}$ & $\mathbf{2 0 1 4}$ \\
\hline Increase enterprise growth & 1 & & & & 1 \\
\hline Attracting and retaining new customers & 2 & 5 & 4 & 2 & 3 \\
\hline Reducing enterprise costs & 3 & 2 & 2 & 5 & 6 \\
\hline $\begin{array}{l}\text { Creating new products or services (innova- } \\
\text { tion) }\end{array}$ & 4 & 6 & 8 & 3 & 4 \\
\hline Improving business processes & 5 & 1 & 1 & 1 & 13 \\
\hline $\begin{array}{l}\text { Implementing and updating business applica- } \\
\text { tions }\end{array}$ & 6 & & & & 12 \\
\hline Improving the technical infrastructure & 7 & & & & 7 \\
\hline Improving enterprise efficiency & 8 & & & & 10 \\
\hline Improving operations & 9 & & & & 2 \\
\hline $\begin{array}{l}\text { Improving business continuity, risk and secu- } \\
\text { rity }\end{array}$ & 10 & & & & 23 \\
\hline Expanding into new markets and geographies & 11 & 13 & 10 & 4 & 5 \\
\hline Attracting and retaining the workforce & 12 & 4 & 3 & 6 & 8 \\
\hline Introducing and improving business channels & 15 & 15 & & & 9 \\
\hline
\end{tabular}

Based on conversations with over 3000 executives globally, IBM produced a report of insights gathered. The report identified technologies on which CIOs are focussing in 2011, and how these compare to what they were focussing on in 2009 as shown in Figure 1 (Horan, 2011). 


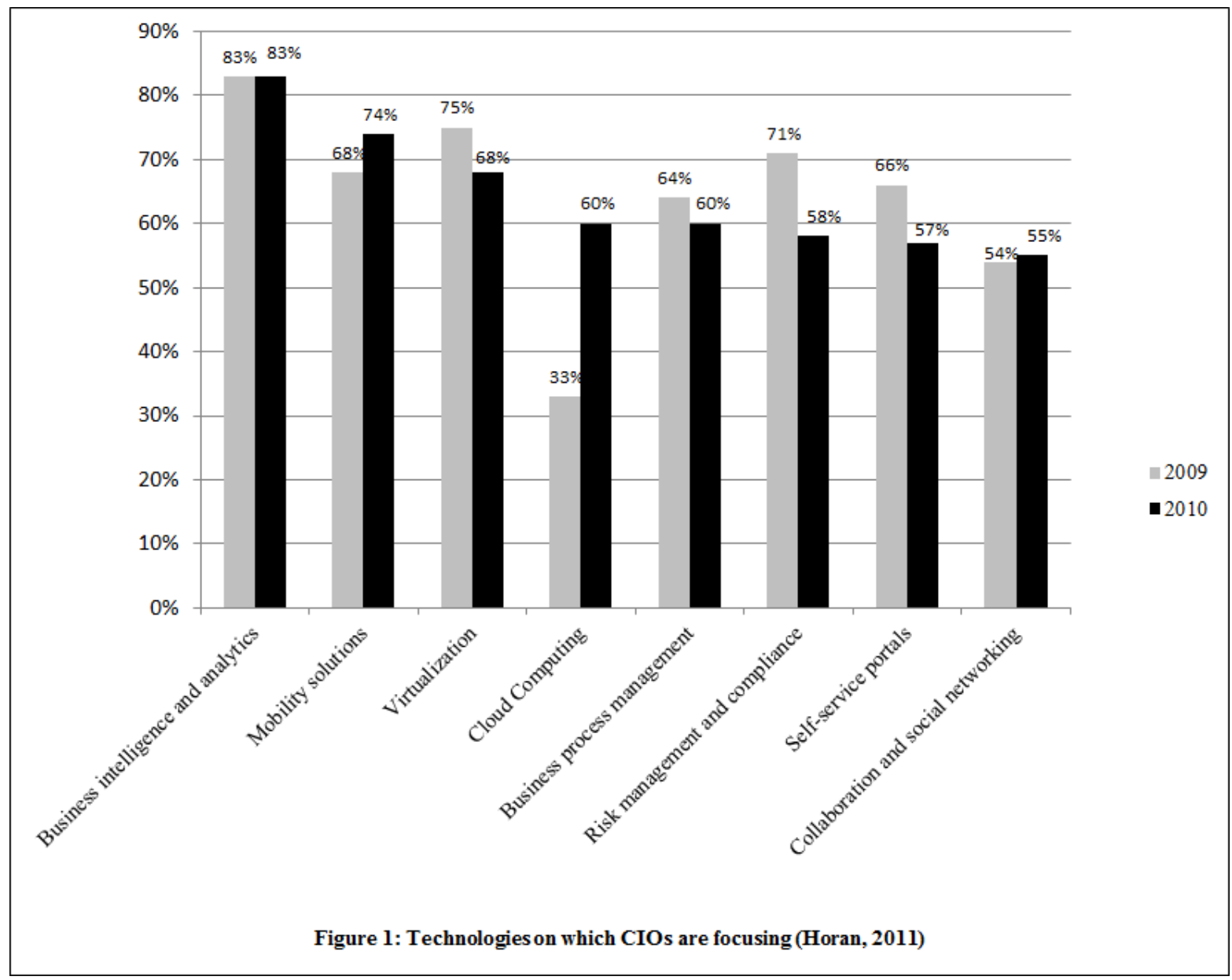

The IBM study also found that the vast majority of CIOs and CEOs identified insight and intelligence, client intimacy and people skills as their top three priorities as where they will focus IT over the next three to five years as shown in Figure 2 (Horan, 2011). 


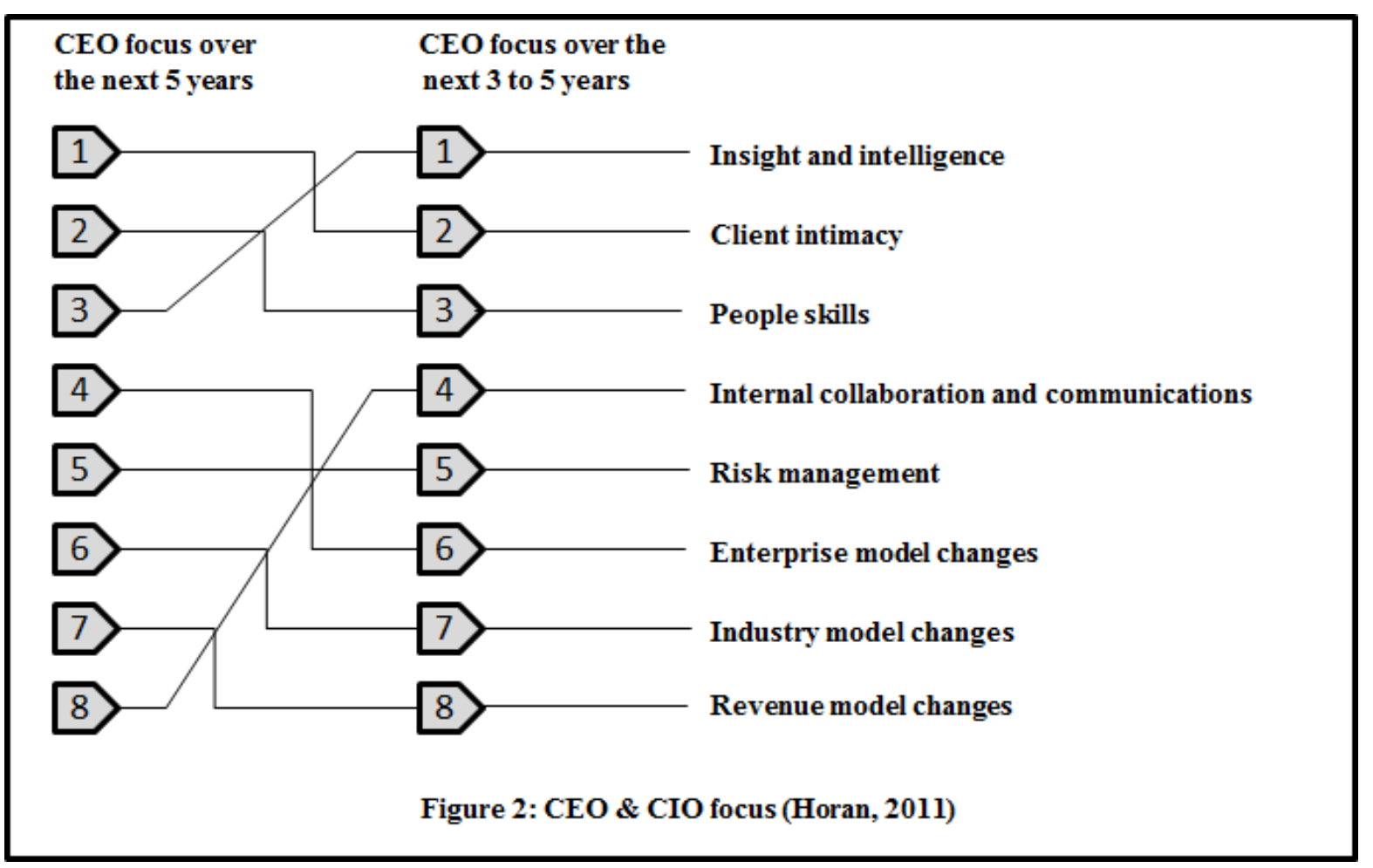

\section{Development of the Framework for an MBA IS Module}

Using information from the literature, a framework was developed for an MBA IS module which was delivered to an MBA course in Germany in 2011. Comparing the technology tables and figures (Tables 1 and 4, and Figure 1), and the management tables and figures (Tables 2 and 5, and Figure 2), it is apparent that there are many similarities and overlaps. Thus it was decided to base the module on the Luftman and Zadeh (2011) study, as it was the most academic study, and the other studies were similar. The framework aimed to ask and answer several questions including: What is worth knowing? What is it good for? When will we ever need this? How do I know? (Postman \& Weingartner, 1969).

The first 6 lectures were delivered by the lecturer, and these were labeled L.1 to L.6 as in Table 8 . The first two lectures covered the introduction to the module, and an introduction to the key IT Management issues. Students were randomly assigned topics from the lectures numbered 1 to 24, which he or she had to research, develop questions, and present to the class in digital format. The instructor gave the students guidelines and additional literature sources. Before the particular class the allocated student was required to load the case study and the questions onto the university's e-learning platform. The student was then expected to present the case study and questions, and facilitate a discussion relating to the case study and questions in class. The class approach is based on interactivity, so each student was expected to come prepared by having read the case study and prepared questions. Students were forced to ask questions, and were assessed on the questions they asked.

The following two lectures (L.3 and L.4) covered an introduction to Web 2.0-5.0, and an introduction to entrepreneurialism and intrapreneurship (entrepreneurship that occurs within a company). Lecture L.5 covered the importance of questioning in businesses, as well as practical exercises and examples of how to question. Lecture L.6 covered guidelines for preparing academic articles, advantages and disadvantages of using models, as well as how to analyze and assess case studies. 


\section{Table 6: Lecture schedule with Case Studies}

\begin{tabular}{|l|l|l|}
\hline No. & Topic & Case Study \\
\hline L.1 & $\begin{array}{l}\text { Introductions/Preliminaries/Assignment alloca- } \\
\text { tions }\end{array}$ & \\
\hline L.2 & Introduction to key IT and management issues & \\
\hline L.3 & Introduction to IS Web 2.0-5.0 & \\
\hline L.4 & Introduction to IS Entrepreneurialism & \\
\hline L.5 & Introduction to Questioning & \\
\hline L.6 & Introduction to Case Studies & \\
\hline 1 & Business intelligence (BI) & US Airline (2008) \\
\hline 2 & Cloud computing & US University (2009) \\
\hline 3 & Enterprise resource planning (ERP) systems & ERP in Oman (2009) \\
\hline 4 & Software as a Service (SaaS, PaaS) & SaaS in US (2008) \\
\hline 5 & Collaborative and workflow tools & Collaborative workflow (2009) \\
\hline 6 & Virtualization & Virtualisation (2010) \\
\hline 7 & Continuity planning/disaster recovery & Australian tax Office (2010) \\
\hline 8 & Security & Singapore hospital (2008) \\
\hline 9 & Business productivity \& cost reduction & Italian aerospace (2010) \\
\hline 10 & IT and business alignment & SAM Alignment (2011) \\
\hline 11 & Business agility and speed to market & Banking Agility (2011) \\
\hline 12 & Business process management and reengineering & Pakistan Public Sector (2008) \\
\hline 13 & IT reliability and efficiency & Chinese University (2009) \\
\hline 14 & Revenue-generating IT innovations & Innovation and Change (2009) \\
\hline 15 & IT strategic planning & SA Stock Exchange (2010) \\
\hline 16 & Project management (PM) & PM information system (2007) \\
\hline 17 & Globalization & UAE Government (2006) \\
\hline 18 & Security and privacy & Slovenian risk management (2010) \\
\hline 19 & Enterprise architecture (EA) & Harmond Bank (2005) \\
\hline 20 & Considerations of IT HR \& leadership of CIO & Tanzanian Health Sector (2006) \\
\hline 21 & Change management & Intranet Redesign (2008) \\
\hline 22 & Knowledge management (KM) & Construction Industry (2008) \\
\hline 23 & Supplier management/Outsourcing & Offshore middlemen (2008) \\
\hline 24 & Social (and ethical) implications of IT & Workplace use of Facebook (2009) \\
\hline & & \\
\hline & & \\
\hline & & \\
\hline & & \\
\hline & & \\
\hline & & \\
\hline
\end{tabular}

The first 8 seminars were based on the top 10 technological issues as identified by Luftman and Zadeh (2011). One of the technological issues (number 6) was incorporated into seminar number 12 , and the vendor specific issue (number 8) was ignored.

Of the 20 management issues from Luftman and Zadeh (2011), number 18 was incorporated with number 1 as both were to do with cost reduction. Number 17 was incorporated into number 13 as both were people related, number 18 was incorporated into number 16 as one sourcing issue, and number 20 (design) was left out due to time limitations. Although one seminar (number 24) was dedicated to social and ethical issues, critical content was introduced into the course at all stages. Students were encouraged to, and readily discussed social issues such as poverty, AIDS, racism, sexism, cultures and power.

Each seminar (1-24) lasted 45 minutes, in which the lecturer gave a lecture of maximum 20 minutes on one of the key information technology and management issues, and provided theoretical background to issues in the case study. The responsible student then made a 10 minute (max- 
imum) presentation to the class concerning the main topics in the case study, and questions raised. The case studies were selected from a wide range of industries, from a range of countries across the globe. Students were allowed to use a number of presentation formats including use of PowerPoint, handouts, blackboard, video, etc. Students were encouraged to make the presentations clear, informative, and interesting. After the presentation, the student facilitated a 15 minute (maximum) discussion (Question \& Answer) session with the class. The student was responsible for ensuring a vital discussion took place, and 30\% of a student's assessment was based on the class presentations.

Participation by students in class discussion and activities was an important part of this course. Students were required to read the required cases and develop questions before coming to class, and a further $30 \%$ of a student's assessment was based on questions asked and answers given. Grades reflected the total impact the student had on the class over the module, through significant and insightful comments, and a demonstration of good problem-solving and analytical skills.

Attendance and administration accounted for $10 \%$ of a student's assessment. Attendance was compulsory at all seminars, and the administration mark was obtained by the student loading the case study and questions onto the university's e-learning platform before the seminar, and by the student loading both the lecturers and their presentation, and a summary of the answers onto the university's e-learning platform within 24 hours of the seminar.

A one hour closed book test based on a case study handed out to the students 48 hours prior to the exam made up the final 30\% of the course mark. Questions were based on the issues covered during the module.

\section{Findings}

Academics should see themselves as both researchers and teachers (Johnston, 2010). Research was first conducted on what to cover on the course. The students and their responses were then observed both in class and in their submissions.

It was observed that although $70 \%$ of students initially classified themselves as technophobes, and stated that they did not see much relevance in the IS module, all the students engaged with the material. Students discovered that the ability to ask questions goes hand in hand with ability to learn, and that questions shape ones direction and focus (Marquardt, 2005). All students participated in the class discussions, and all of them incorporated stories from personal experience. All students discussed what they would do regarding various aspects of technology once in the workplace, and all students integrated material from other MBA modules into the discussions.

\section{Conclusions}

Today there is so much information available on so many subjects, but what is relevant and significant is not easy to discover, and this is one of the main roles of a teacher. Doing research into course content (what should be covered) for each course can be beneficial to both the lecturer and the students. A lecturer should help students discern the relevant from irrelevant, the significant from the insignificant, and the applicable from the inapplicable (Dreyfus, 1999).

An interactive method focusing on questioning and discussion while working on unstructured and complex problems, and promoting an integration of knowledge of business, strategy, psychology, and information technologies appears to work at an MBA level. Information can only be turned into knowledge if a student is both committed and involved. The heart of education should be to develop a student's ability to question and to use his/her judgment in everyday life, so priority should be given to the formation of questions and judgment rather than memory and recall (Foglia, 2004). 


\section{References}

Altbach, P. G. (2001). Academic Freedom: International realities and challenges. Higher Education , 205219.

Blanton, P. (2002). All I need to know about teaching I learned from my students. The Physics Teacher, 557-558.

Brancheau, J. C., Janz, B. D., \& Wetherbe, J. C. (1996). Key issues in information systems management. MIS Quarterly, 20 (2), 225-242.

Dreyfus, H. L. (1999). Anonymity versus commitment: The dangers of education on the internet. Ethics and Information Technology, 15-21.

Foglia, M. (2004). Michel de Montaigne. Retrieved November 21, 2009, from Stanford Encyclopedia of Philosophy: http://plato.stanford.edu/entries/montaigne

Gottschalk, P., Watson, R. T., \& Christensen, B. H. (2000). Global comparisons of key issues in IS management: Extending key issues selection procedure and survey Approach. Proceedings of the 33rd Hawaii International Conference on System Sciences. Maui: HICSS-33.

Johnston, K. A. (2010). What it means to be a teacher in a higher education context today - with emphasis on South Africa. Proceedings of InSite 2010. Cassino: Informing Science Institute.

Laudon, K. C., \& Laudon, J. P. (2012). Management information systems. Upper Saddle River: Prentice Hall.

Luftman, J., \& Ben-Zvi, T. (2010). Key Issues for IT Executives 2010. MIS Quarterly Executive, 9(4), 263273.

Luftman, J., \& Zadeh, H. S. (2011). Key information technology and management issues 2010-11: An international study. Journal of Information Technology, 193-204.

McDonald, M., \& Aron, D. (2011). Reimagining IT: The 2011 CIO Agenda January 2011. Gartner.

Pearlson, K. E., \& Saunders, C. S. (2010). Managing and using information systems: A strategic approach. Hoboken: Wiley \& Sons.

Postman, N., \& Weingartner, C. (1969). Teaching as a subversive activity. Penguin Education.

Raskino, M. (2011). CEO concerns in 2011 and the IT implications. Gartner Symposium/ITxpo Africa 2011. Cape Town: Gartner.

Turban, E., Leidner, D., McLean, E., \& Wetherbe, J. (2008). Information technology for management. Hoboken: John Wiley \& Sons.

\section{Biography}

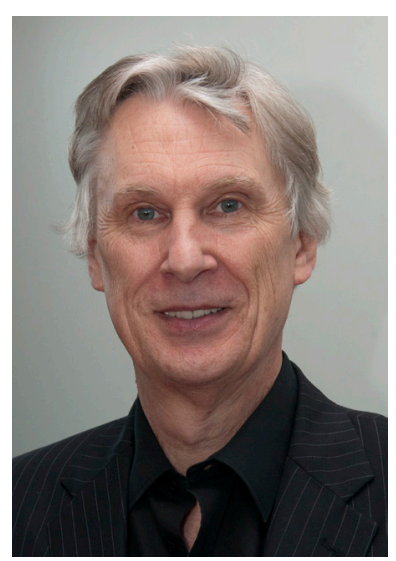

Kevin Johnston is an associate professor in the Department of Information Systems at the University of Cape Town, South Africa. Before becoming an academic, he worked for 24 years in industry. His main areas of research are IS Change, IS Management, and IS education. 